or we will sell the Republic of Mexico for $\$ 6,000$, provided that it is not taken before we hear from you."

Another sheaf of material in the collection are the incoming letters - vague inquiries, telegrams demanding prompt delivery, loud complaints and criticisms, and letters requiring the formula which Hjalmar Schacht as Currency Commissioner in Germany found so useful, "I have been much interested in your illuminating suggestions on the. . .." One of the more ingenious had already seen motion picture possibilities for use in that great national arena - the $\mathrm{I} 896$ presidential campaign.

Of more seriousness are the criticisms from picture houses over the country as to the quality of the films. E. F. Albee, Manager of Keith's Theatre in Boston, succinctly declares that instead of the machine being a feature it has become a farce. As the great fights of the day lost their charm, some substitute had to be found and the whole development of the motion picture industry, according to Terry Ramsaye in his entertaining "A Million and One Nights," was to be foreseen in the popularity of the short sketch, "The May Irwin - John C. Rice Kiss," popularly known as the "Kiss."

An order from Ottawa describes in title thirteen films popular in the 9o's: Sea Waves, Pickaninnies, Fire Scene, Milk White Flag, Ocean Greyhound leaving Wharf, Cock Fight, Bucking Broncho, Carnival, Kiss, Herald Square, Sun Dance (colored film), Monroe Doctrine, and Cissy Fitzgerald. The three particularly demanded are Sea Waves, Sun Dance, and the famous Kiss.

\title{
Tariff In 1820
}

That the tariff conflict of agricultural and manufacturing interests in the United States was not much different a hundred years ago than it is today is exemplified in an acquisition of the Business Historical Society, "A view of the ruinous consequences of a dependence on foreign markets for the sale of the great staples of this nation, Flour, Cotron, and Toвacco." The author is Matthew Carey, one of the most vociferous protectionists writing after the crash of 1819 .

This forty-page tract published in 1820 is addressed to the Congress of the United States after having been "read before, and ordered to be printed by, the Board of the Pennsylvania Society for 
the promotion of American Manufactures." The title-page is well fortified with quotations from Governor Wolcott, then in command in Pennsylvania, Lord Chatham, the political philosopher Postlethwaite, and "Horat." in Latin.

That the quality of the material is of the high caliber recently given to the American public in the Hawley-Smoot campaign is evidenced by a statement in the preface that the author has "depended more on strong and decisive facts, than on abstruse reasonings. The former are almost universally safe guides - the latter mere ignes fatui, which too generally lead astray."

Carey begins his argument with the statement that he has been unjustly regarded as hostile to farmers and merchants whereas, he declares, there is an identity of interest between them. Rather than waiting upon a precarious foreign market subject to competition in cotton from East India, the wheat states of New York, New Jersey, Pennsylvania, and Ohio suffering from sales in Odessa, Virginia tobacco competing with European rivals - not to speak of potential battles in these commodities with South America we should in an enlightened fashion give the home manufacturer a chance. Let the manufacturers who previously from want of protection returned to the soil for a livelihood go back to their native occupations. This would produce a two-fold beneficial effect "diminish the number of producers, and of course the surplus of agricultural productions, with most of which foreign markets are over-stocked. And it would moreover furnish the farmers with a certain domestic market instead of a precarious foreign one."

\section{The Trotters - Colonial Importers}

THE history of one of America's oldest importing houses contained in records for the period from 1798 to 1916 has been presented by Mr. and Mrs. William Henry Trotter of Philadelphia. William Trotter, Quaker, who organized the company in 1789 , was an importer of metals, leather goods, textiles and miscellaneous commodities.

A prosperous business with the home country was shattered with the War of 1812 , and William Trotter and then later his brother Nathan turned to the Orient and became importers of tea and spices. But trade with England was safer and more remunerative, 